\title{
“You're the boss, yo!": Role-Play in Digital Multimodal Composition of Newcomer Youth
}

\author{
AMIR MICHALOVICH \\ University of British Columbia
}

\begin{abstract}
This case study explores how two 16-year-old newcomer youth in a Canadian secondary school navigated the digital multimodal composition process through role-play in their first digital video production at school. Employing a qualitative, case-study design, the study shows how the youth playfully accentuated collaborative over coercive power relations, as well as repositioned and represented their imagined identities as they played different assigned roles in the filmmaking process. The implications of these findings are discussed for educators and researchers considering digital multimodal composition as a classroom literacy practice.
\end{abstract}

\section{Introduction}

As migration continues to rise in Canada, learners from immigrant and refugee backgrounds increasingly form culturally and linguistically diverse English Language Learning (ELL) classes (Early et al., 2017). Newcomer students, migrants who have been in the receiving country for 1 to 10 years (Oikonomidoy et al., 2019), define a unique population of English Language Learners (ELLs), yet characteristics within the population are significantly diverse (Cummins et al., 2012; Shapiro et al., 2018; Warriner et al., 2020). Exploring this diversity through context- and case-specific research is crucial for researchers and educators to understand how to better address these learners' needs.

While studies in Canada have shown that ELLs have a high drop-out rate from school (Watt \& Roessingh, 1994, 2001), newcomer ELLs from refugee backgrounds, low socio-economic status (SES), or marginalized communities, have an especially high dropout rate (e.g., Gunderson, 2007; Toohey \& Derwing, 2008). Some of the challenges newcomers face in Canadian classrooms may play a role in this outcome, such as the need to learn in a second or additional language, and to catch up to their grade level peers in both conversational and academic English/French (Cummins et al., 2012; Early \& Marshall, 2008). For refugee-background learners, there is also the possibility of interrupted schooling (Custodio \& O'Loughlin, 2017), limited literacy in their first language(s) (L1s; Warriner et al., 2020), or difficult experiences related to forced migration (McBrien, 2005; Reynolds \& Bacon, 2018).

Digital multimodal composition (DMC), i.e., the use of digital tools to make meaning with multiple modes (e.g., languages, visuals, sounds, etc.; Hafner, 2018), has been shown to engage learners, ELLs included, in school learning and literacy practices (see Smith, 2014; Smith et al., 2020). DMC allows for multiple entry points to learning and texts (Jewitt, 2008), inviting ELLs to express and represent their identities (e.g., Kim, 2018), develop as multimodal designers (e.g., Burke \& Hardware, 2015), facilitate their social connections (e.g., Karam, 2018), and enhance their language and literacy learning (e.g., Hepple et al., 2014). As the following sections clarify, play has been recognized for 
its important relationship with learning, yet, seldom has play been empirically explored as part of newcomer learners' DMC in school settings, especially role-play and especially among adolescents.

This study begins to address this gap in research, guided by the following question: How did two newcomer youth, one from a refugee background and the other from an immigrant background, navigate the DMC process through role-play in their first digital video production at school? Employing a qualitative, case-study design, the study shows how the youth playfully accentuated collaborative over coercive power relations, as well as repositioned and represented their imagined identities as they played different assigned roles in the filmmaking process. These findings bear important implications for educators and researchers considering DMC as a classroom literacy practice to advance the language and literacy learning of newcomer youth in school settings.

\section{Theoretical Perspectives}

This study draws from sociocultural theory and a multiliteracies approach to literacy, whereby literacy is understood, not as a set of autonomous skills that are similar everywhere, but rather as a social practice that varies across contexts (Barton \& Hamilton, 2000; Street, 1984) and spans multiple modes of meaning-making beyond reading and writing in language (e.g., Cope \& Kalantzis, 2005; New London Group, 1996).

In sociocultural theory, social practices are understood as interactions that include two or more individuals, culturally-shared goals, repertoires of actions, culturallyconstructed tools (e.g., artifacts), and sign systems for communicating meaning (Vadeboncoeur, 2017). Through participation in social practices, which involves internalizing and transforming these repertoires of actions and communicative resources and tools, participants develop psychological functions and abilities (Vygotsky, 1978). Literacy as a social practice thus means that literacy practices are inter-mental processes in which cultural tools and communicative resources such as reading and writing are developed, used, and learned socially among individuals, "existing in the relationships between people, within groups and communities" (Barton \& Hamilton, 2000, p. 8). Literacy practices are therefore developed in a socially mediated experience, a Zone of Proximal Development (ZPD), which ideally bridges "the distance between the actual development level as determined through independent problem solving and the level of potential development as determined through problem-solving under adult guidance or in collaboration with more capable peers" (Vygotsky, 1978, p. 86).

As social relationships are so central to literacy practices, the latter are imbued with power relations, understood as "relations among individuals, institutions and communities through which symbolic and material resources in a society are produced, distributed and validated" (Norton, 2013, p. 47). This study draws on Cummins (2000) in distinguishing between coercive and collaborative power relations. Coercive power relations subscribe to a finite understanding of power and contribute to the disempowerment of students and communities - especially those who are marginalized or non-dominant. Conversely, collaborative power relations subscribe to an understanding of power as generated through positive interactions rather than having a fixed quantity, and contribute to the empowerment of students and communities. As micro-interactions of students and teachers are imbued with power relations, they are thought to be "the most immediate determinant of student academic success or failure" (Cummins, 2000, p. 44). 
In literacy practices, cultural tools and resources mediate-through their affordances and limitations - how agents represent meaning that is situated in and enacted as social action (Vygotsky, 1978; Wertsch, 2009). From a multiliteracies perspective, the use of such cultural tools and resources is a process of design, which may draw from different modes of meaning-making, such as the linguistic (including multiple languages), visual, spatial, gestural and audial modes (Cope \& Kalantzis, 2005; New London Group, 1996). A sociocultural, multiliteracies approach to literacy highlights that $21^{\text {st }}$ century learners should be able to harness (1) the affordances of composing in multiple modes and (2) their own diverse social and cultural knowledge, in order to become agentive, creative, and critical designers with access to social power, civic participation, economic gain, global citizenship, and diverse lifeworlds (Serafini \& Gee, 2017).

The study further draws from theoretical perspectives on (1) play and multimodal composition, and (2) identity, literacy engagement, and imagination, detailed below.

\section{Play-Based Approach to Multimodal Composition}

Although there is no common definition of play among scholars, established definitions often include features of activities such as spontaneity and lack of rigid goals, and qualities of felt experience such as pleasure, anticipation, flow, and surprise (Mardell et al., 2016). Some scholars argued that play is not always fun, as it can be challenging and difficult (e.g., Fisher et al., 2017; Sicart, 2014). Yet, at the very least, play generates an expectation for playfulness, which can be defined as "the disposition to frame or reframe a situation to include possibilities for enjoyment, exploration, and choice" (Mardell et al., 2016, p. 3).

An important dimension of play is its quality as "an attitude toward the use of mind [...] a test frame, a hot house for trying out ways of combining thought and language and fantasy" (Bruner, 1983, p. 69). As such, play is modally rich (Wohlwend et al., 2017), and playing with modal resources and materials encourages "textual explorations, reconfigured teaching and learning relationships, and new roles with and through media technologies and media texts" (Vasudevan et al., 2010, p. 7). A play-based approach to pedagogy thus highlights the importance of carving out spaces for play across the curriculum and across modes (Fisher et al., 2017).

Furthermore, play can be transformative through laughter, a medium of play (Vasudevan, 2015). Bakhtin (1984) highlighted laughter's force in liberating from "fear of the sacred, of prohibitions, of the past, of power" (p. 94). Among adolescents, Vasudevan (2015) argued for the value of laughter in seeding the development of multimodal texts. In children's videos, laughter and humor were shown to break tensions and create humorous narratives (Pandya, 2019) that "rupture the silence and solemnity of schooling" (Pandya \& Mills, 2019, p. 14).

Fisher et al. (2017) cited Sutton-Smith's (1997) notion that play is "paradoxical in that it occupies a liminal space between reality and unreality" (Fisher et al., 2017, p. 57). Relatedly, Vygotzky (1933) highlighted the imaginative quality of play, which affords an opportunity to act as if a person or an object is other than what it is, liberating the player from the constraints of the concrete context. Role-play is thus understood as a form of learning in the ZPD. Through imaginary social situations, roles and rules, role-play drives

one to act beyond their current level, to perform a task before they are competent in it (performance before competence; Cazden, 1997). In this sense play, and role-play 
especially, have a mutually-constitutive relationship with learning (e.g., De Castell \& Jenson, 2003; Dewey, 1916; Huizinga, 1950; Lotherington \& Jenson, 2011; Vygotsky, 1978).

Playfully stepping into a role helps gain distance from oneself, which facilitates perception of self, but also helps imagine possible futures (Vygotsky, 1926). This reinforces the claim by Holland et al. (2001) that play is a space for identity authorship. In the context of media production, Kendrick et al. (2018) showed how playfully enacting the roles of videographer and journalist in filmmaking afforded adolescent girls in rural Kenya opportunities to "perform a new identity in an authentically created context, allowing for a unique kind of risk-taking and error-making without real-world consequences" (p. 3). Similarly, Soep (2005) showed how adolescent boys who were engaged in creative play and role-play through filmmaking at home were able to "practice the kind of aesthetic labor they someday hoped to do for real, and for pay" (p. 190) and experiment with exaggerated masculine identities, while expressing intimate and emotional connections through their collaboration. Relatedly, Medina and del Rocío Costa (2013) showed how elementary students were able to critically explore global social discourses about gender and race (among others) through role-play in an inquiry project that included producing telenovelas. Importantly, studies that examine play and role-play in media production contexts often focus on children (e.g., Wohlwend, 2018), and those that address youth are often situated in out-of-school settings (Vadeboncoeur, 2017), as in two of the above studies.

This study explores the extent to which role-play may provide opportunities for newcomer youth to perform and practice, in a school setting, new roles and identities that are currently beyond their reach, as a stepping stone to becoming competent in DMC practices.

\section{Identity, Literacy Engagement, and Imagination}

Norton (2013) defined (social) identity as "the way a person understands his or her relationship to the world, how that relationship is structured across time and space, and how the person understands possibilities for the future" (p. 4). According to this definition, identity is understood as a site of struggle where people assume and withdraw from multiple subject positions that might conflict with each other.

Identity is thus dynamic and changing over time rather than static and fixed; it consists of the multiple and dynamic ways in which people position themselves or are being positioned by others in various contexts. Golden and Pandya (2019) drew from Harré and Langenhove (1991) in defining positioning as "the discursive construction of stories and relationships that build meaning and make an individual person's actions intelligible" (2019, p. 212). Considering identity as a site of struggle, one may contest their positioning, through repositioning ${ }^{1}$ (Golden \& Pandya, 2019). Because positioning is tied to discourse, it is usually more dynamic than a role, which implies a more static identity (Harré \& Langenhove, 1991). Admittedly, roles may lose some of this static quality during role-play, but the spatial metaphor in the notion of positioning remains useful for understanding how identities are negotiated.

Importantly, it is through affirmation of their identities that learners engage in literacy practices (Cummins \& Early, 2011). Affirmation is understood as recognition of

\footnotetext{
${ }^{1}$ In this paper, I use the term repositioning (Golden \& Pandya, 2019), which is comparable to the notion of second-order positioning, coined by Harré \& Langenhove (1991).
} 
learners' investment (Norton, 2013) in language and literacy learning, i.e., the social and cultural capital that learners currently possess and that which they desire to obtain. In the context of this study, the notion of learners' engagement in literacy practices is interchangeable with the notion of literacy engagement, defined as learners' "involvement in activities and processes that develop their knowledge, skills, and attitudes for comprehending and composing a variety of texts in oral, print, visual and digital formats" (Ng \& Graham, 2018, p. 615). Considered as a social process in addition to an individual process, learners' literacy engagement is nested in social contexts and relationships to the social realm (Smagorinsky, 2001), including the possession of and desire for social and cultural capital. Affirming learners' investment thus contributes to their engagement in literacy practices, including multimodal literacies (Jiang, 2018).

Affirmation of learners' identities is further understood as valuing both how they currently position themselves and how they imagine themselves in the future (imagined identities), including the communities to which they hope to belong (imagined communities) (Norton, 2013). The notion of imagined communities was introduced by Anderson (1983) to highlight the meticulous construction of national identities through vernacular languages, artifacts, and print texts, among others, that forge a "deep horizontal comradeship" (p. 7) among people who do not know each other; Taylor (2004, 2007) explained how this notion represents an historical, modern shift in Western societies from a vertical, hierarchical social imaginary (e.g., the privileging of kings or priests as mediators of higher orders and times) to a horizontal, de-centered social imaginary, where each member of society has direct access in imagining their community and negotiating their participation in it; Appadurai (1996), theorizing imagination as a social practice, suggested that such negotiations are work that individuals undertake nowadays with their imagination to explore their possible lives beyond the scope of the nation state, through globalized mass media. Although national and global imaginaries permeate classrooms and literacy practices in important ways (e.g., Medina \& del Rocío Costa, 2013; Medina \& Wohlwend, 2014; Soep, 2005), this study focuses on the local dimension of imagined communities and identities in language and literacy classrooms.

The notion of identity text, as defined by Cummins and Early $(2011)^{2}$, emerged as an instructional tool that recognizes how identity affirmation contributes to literacy engagement (e.g., Cummins et al., 2015, 2017; Giampapa, 2010; Nagle \& Stooke, 2016; Zapata \& Ribota, 2020). By encouraging learners to create and present texts ${ }^{3}$ about their social and personal experiences in a variety of modes and their combinations, it was suggested that learners' identities will be affirmed, and their literacy engagement will increase. Identity texts were specifically designed to advance the academic achievement of newcomer learners in the process of learning a second (or additional) language, and marginalized learners and learners from low SES backgrounds (Cummins et al., 2015). Recently, identity texts have been taken up with additional populations as well (see Prasad, 2018).

Using a different approach from identity texts, Boisvert \& Rao (2015) illustrated how video can be used for self-modeling, facilitating self-efficacy and rapid learning

\footnotetext{
${ }^{2}$ For a different use of the term identity text, see Medina and Wohlwend (2014).

${ }^{3}$ Although in semiotics, the notion of text can relate to anything that "can be analysed using the techniques of semiotics" (Bateman, 2014, p. 13), Cummins and Early's (2011) notion of identity text usually refers to artifacts produced by learners as part of pedagogical activities.
} 
among adolescent ELLs. In editing-out footage in which learners' performance was less than their best, the final videos depicted "a future mode of success" (p. 40) or a positive self-review, in which learners saw themselves as successful and capable English speakers.

Recognizing the potential of role-play and DMC for learning, identity affirmation and literacy engagement, role-play was employed in this study to support newcomer youth's first video production in their school setting, with the aim of understanding how they might navigate the DMC process through role-play.

\section{Research Context and Participants}

\section{Methodology}

The study was conducted in a secondary school known to have many ELLs (about $15 \%$ ) in a large Western Canadian city. It was situated in an elective Media Skills class for 10 students enrolled in a district-funded program that consisted mostly of newcomers facing challenges with English and social-emotional skills. Through recommendation by colleagues, I worked in this program as a volunteer from the nearby university between 2019-2020 (one to two times a week), helping with one-on-one support and classroom instruction.

The participants were two newcomer 16-year-old youth: Chen (pseudonym), who migrated in 2016 from China, and Ahmed (pseudonym), who was forcefully displaced from Syria and lived several years in Turkey, before migrating to Canada in 2016. At the time of the study, Chen was literate in his L1 Chinese (spoken Cantonese, written Mandarin), and his English (comprehension and production) was considered by provincial ELL standards (BC Ministry of Education, 2017) at a level-two out of five (Developing). Ahmed spoke Turkish as an L1, some Arabic, and was hoping to retrieve his lost spoken Kurdish. He was not literate in those languages, but he was becoming literate in English. His English (comprehension and production) was considered by the provincial ELL standards at a level-one (Beginning). Ahmed's schooling was significantly interrupted due to his forced displacement. While Chen lived with his family, Ahmed lived with a foster family, though his family lived nearby. The youth were classmates for eight months before the study, but were not close friends previously.

The 5-week project, conducted in collaboration with the teacher and all students in the class, consisted of video production based on the interests of the students. Upon my invitation to all students to participate in the study, Chen and Ahmed chose to participate, perhaps because I had already worked with them extensively as a volunteer.

This study is part of my multiyear research with refugee-background youth producing videos in a school setting in their settlement context. I bring to the study extensive experience and interest in filmmaking in education research and practice, and my recent experience of migrating to Canada. I subscribe to an asset-based educational approach that values newcomer youth's communicative repertoires and intellectual and cultural resources rather than a deficit-oriented approach that focuses on remediation (Warriner et al., 2020). Thus, my framing of their challenges in school is never an attempt to essentialize them based on these challenges, but rather to share where they should be supported, considering the sociohistorically-constructed schooling practices and conventions in the context in which they currently live and learn.

Ethics approval for this study was provided by the university's behavioral research ethics board. 


\section{Study Design and Procedure}

A case study methodology (Yin, 2018) was employed to provide rich, in-depth, context- and case-specific data, with the case being the video production project which involved the two newcomer youth and me as a facilitator. I also employed a multimodal ethnographic approach (Flewitt, 2011), attending to the social and cultural context of the youth's interactions and to how they digitally composed in multiple modes. As with other studies employing this approach (see Dicks et al., 2011), the research goal determined the order of priorities, in this case foregrounding analysis of youth's interactions over modeuse; however, mode-use informed the analysis as I treated modes as units of meaning (Woolf \& Silver, 2018) in analyzing the youth's videos (see Table 1).

Under my close guidance on camerawork and video editing (using Adobe Premiere Pro) the youth produced their one-minute videos collaboratively in five lessons (each lasting 85 minutes) as detailed in Figure 1. My support as a facilitator and tutor was ongoing and included both technical how-to and encouragement and reassurance. Although the youth determined the content and form of their videos, I intentionally employed roleplay to structure their collaboration in terms of relevant filmmaking roles, which I introduced and reminded them of: director, narrator, editor, filmed subject, cameraperson, as well as interviewer and interviewee. In one case, navigating my liminal position as a volunteer and researcher, I humorously used the informal term "boss" in initially explaining the role of director to highlight the low stakes of this interaction. As will be shown, Chen and Ahmed took up this invitation playfully.

Although the youth initially planned their videos to be about their phone use, they ultimately turned them into what Cummins and Early (2011) would call identity texts. The videos introduced Ahmed and Chen - their habits and backgrounds - and depicted them walking in the hallways, stairs, foyer, and cafeteria of the school, looking outside the window, drinking soda, and playing with an iPad or their phones (see summary of the DMC process in Figure 1).
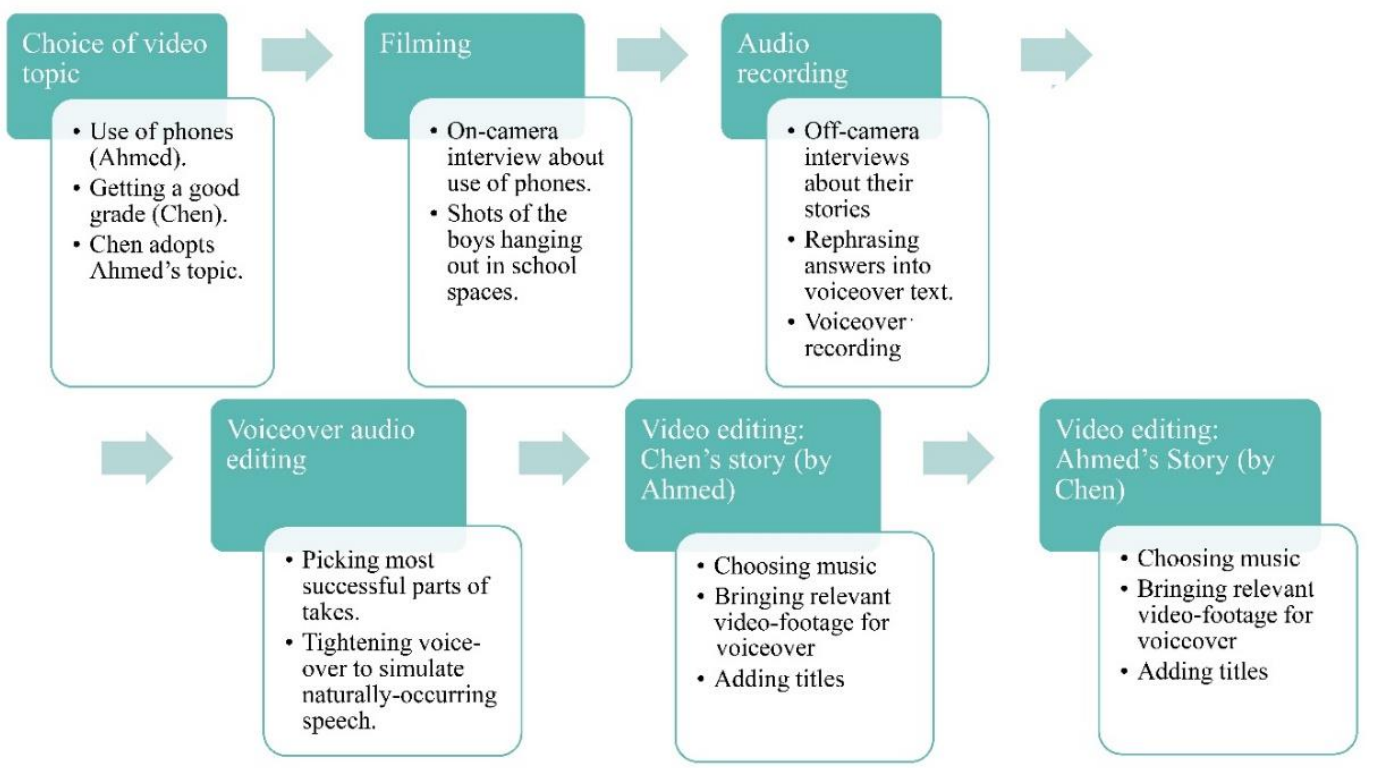

Figure 1. DMC process 


\section{Data Collection and Analysis}

Data were collected during April and May 2019 (totaling about 7 hours), and consisted of youth's videos, an audio recording of the filming session, computer screen recordings (including audio) of four composing sessions, which included informal interviews with the youth, as well as an audio recording of a 40-minute semi-structured interview with both of them after the project was complete.

Data analysis followed the six stages of thematic analysis as specified by Braun and Clarke (2006, 2012) and as extensively detailed, drawing from Smagorinsky (2008), in Table 1 (see the appendix) and Figure 2. Analysis was predominantly inductive, i.e., it did not begin by applying theoretical concepts and their relationships to the data, but those were rather identified at a later stage to interpret emerging descriptive patterns collected in codes and their intersections. Analysis was directed toward identifying themes, i.e., patterns of meaning in the data that are broader, more abstract and/or theoretical than descriptive codes, relevant to the research question, and fairly pervasive in the data (Braun \& Clarke, 2012).

Analysis was influenced by interactional sociolinguistics (IS), especially microethnography, in relying on the assumption that researchers can access the working consensus among individuals in interaction about the definitions of situations, i.e., answer the question "What is going on?", because such definitions need to be shared publicly among individuals for interactions to proceed (Streeck \& Mehus, 2005). However, analysis did not fundamentally employ IS, as it did not specifically set out to examine how the use of language informs social interaction (Gumperz, 1999).

To address validity threats (Maxwell, 1992), I relied on my long-term involvement in the field, a constant search for discrepant evidence, reflexive awareness through memos (Maxwell, 2012; Miles et al., 2020), and my role as close facilitator in the youth's DMC process, which afforded an opportunity for me to participate in the co-construction of multimodal data (Low \& Pandya, 2019) and gain a closer perspective on youth's design choices.

Based on my experience with ATLAS.ti, I used it to manage the volume of unstructured and multimodal qualitative data, recognizing the contrast between software tools, that are fixed and prearranged, and qualitative analysis, which is iterative and emergent, but also how this contrast can be bridged by translating analytic tasks to the use of appropriate software features (Friese et al., 2018; Woolf \& Silver, 2018), as explained in Table 1 in the appendix. 


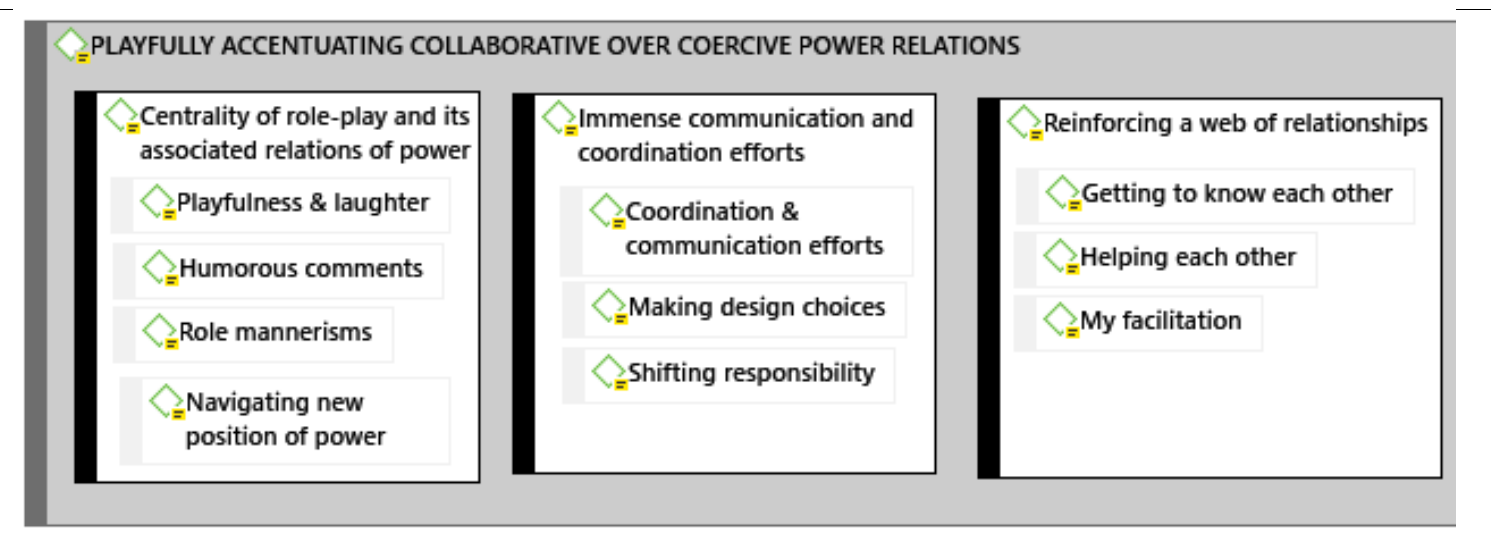

REPOSITIONING AND REPRESENTING THEIR IMAGINED IDENTITIES

Reflection of imagined identities as integral to composition

Identity reflection: Positive

Identity reflection: Negative

Conflicts in interaction

Identity representation

Work on language use

Taking initiative

Figure 2. Visualization of data reduction from substantive and theoretical codes (white background) to final themes (gray background)

\section{Findings and Discussion}

Analysis led to the identification of two interweaving thematic patterns, each of which highlights a distinct way in which newcomer youth navigated the DMC process through role-play: (1) playfully accentuating collaborative over coercive power relations; and (2) repositioning and representing their imagined identities. Each thematic pattern is discussed below. Excerpts were chosen based on their richness for representing the themes.

\section{Playfully Accentuating Collaborative over Coercive Power Relations}

Inevitably, the explicit assignment of roles positioned youth in specific power relations, as one youth always had to work for the other. These roles - although they should not be thought of as mutually exclusive, fully distinct from each other, or necessarily enduring - included those of director ("boss"), interviewer, narrator (through voiceover), video and sound editor, cameraperson, filmed subject (playing oneself), and interviewee.

The roles entailed challenges, some of which could be experienced by youth in daily contexts but were clearly heightened and highlighted by the role-play. The challenges included having to manage the responsibility for moving the filming and editing forward (e.g., what to do next, technically and conceptually) and communicating what they wanted to do as directors, editors, interviewers and so on. Thus, the roles raised tensions in youth's power relations. Nevertheless, through recurring and prolonged laughter and playfulness, the youth attenuated the tensions and challenges induced or heightened by the roles, accentuating collaborative over coercive power relations (Cummins, 2000).

Considering first the tensions and challenges associated with the youth's assigned roles, it is noteworthy that when situated in the role of editor or filmed subject, they would 
each highlight the responsibility their partner had as a director. In one instance, Ahmed called Chen "bad boss" when Chen, as a director, became impatient with Ahmed's slower pace as an editor, due to Ahmed's beginning digital literacy and English proficiency. Such instances exemplify the tension between their newly adopted positions of power afforded by the roles and their identity-positionings as classmates.

In the following excerpt, Chen knew that as a filmed subject he needed to play himself reading in his phone in the school's cafeteria, but he was not sure how to do that. He thus asked Ahmed, the director and cameraperson, for specific instructions, but Ahmed experienced challenges in expressing precise instructions in English, and continued providing general instructions:

\section{Excerpt 1:}

Ahmed: I, I take you, you, you, you, reading.

Chen: So you want, what do you want me to...

Amir: Okay. So we will take you reading and then also Ahmed.

Chen: Reading or something else?

Ahmed: You do... You do, do anything.

Chen: I ah... I... You're the boss, yo!

Ahmed: Okay.

Chen: I, I...

Ahmed: Read!

Chen: I can sit there and play my phone or something else? Do you want, what should... Ahmed: Okay, read.

As the youth played their roles, they experienced the responsibility of communicating instructions and working in collaboration with each other. This arguably destabilized the dynamics of power in their relationship as classmates. As directors, camerapersons, and interviewers, they had to make decisions and communicate accurately, each telling the other what to do. As editors, filmed subjects, and interviewees, they had to understand and then fulfill the expectations of the other, e.g., the director ("the boss"). Carefully navigating these new power relations, different from their day-to-day relationship as classmates, was strenuous for them. The excerpt also shows that, as the facilitator, I was involved in trying to help them manage this tension ("Okay. So we will take you reading and then also Ahmed").

Importantly, these power relations were inextricably linked with the youths' different proficiency and literacy levels in English, granting each of them different levels of confidence with the challenging language work associated with the roles. This work required the youth to coordinate their actions and instructions, in addition to formulating questions and answers to each other in interviews, rephrasing answers in their own words, as well as recording and editing their voiceover. Because Ahmed was late to literacy, had had his schooling interrupted, and his English was at a beginning level, the tensions of power relations associated with the roles were more pronounced for him.

Alongside the challenges, laughter and playfulness were no less central in the project. In fact, their ongoing presence clearly attenuated the tensions and challenges associated with the roles. From the outset, the youth playfully roamed the school hallways searching for a location to film their interviews with each other. It was as if for this brief moment in time, when all other students were in class, they experienced the low-stakes quality of role-play, were temporarily freed from the seriousness of schooling (Bakhtin, 
1984; Pandya, 2019; Pandya \& Mills, 2019; Soep, 2005) and "liberated from situational constraints" (Vygotsky, 1933, p. 11). Risk-free, they could thus playfully and freely express themselves, relieve their tensions, and 'claim' these spaces as their own (see Figure 3). Playfully, they called each other "Mr. Ahmed" and "Mr. Chen", treating each other as interviewers and interviewees of eminent statuses, used light-hearted music and gestures in their videos, and would often burst out laughing as they played these roles and simulated various kinds of relationships with each other. As facilitator, I continuously supported such interaction by playing along.

Playfully moving in and out of the roles and thereby relieving some of the tensions associated with them was possible because of the liminal space that play occupies between reality and unreality (Sutton-Smith, 1997). Indeed, it is through role-play that the youth could attempt to do challenging tasks that they would otherwise not be able to complete on their own (Cazden, 1997), "thinking and feeling their way through the role, making meaning and sense of it, as they improvise within the imagined frame of the situation" (Vadeboncoeur, 2017, p. 101).
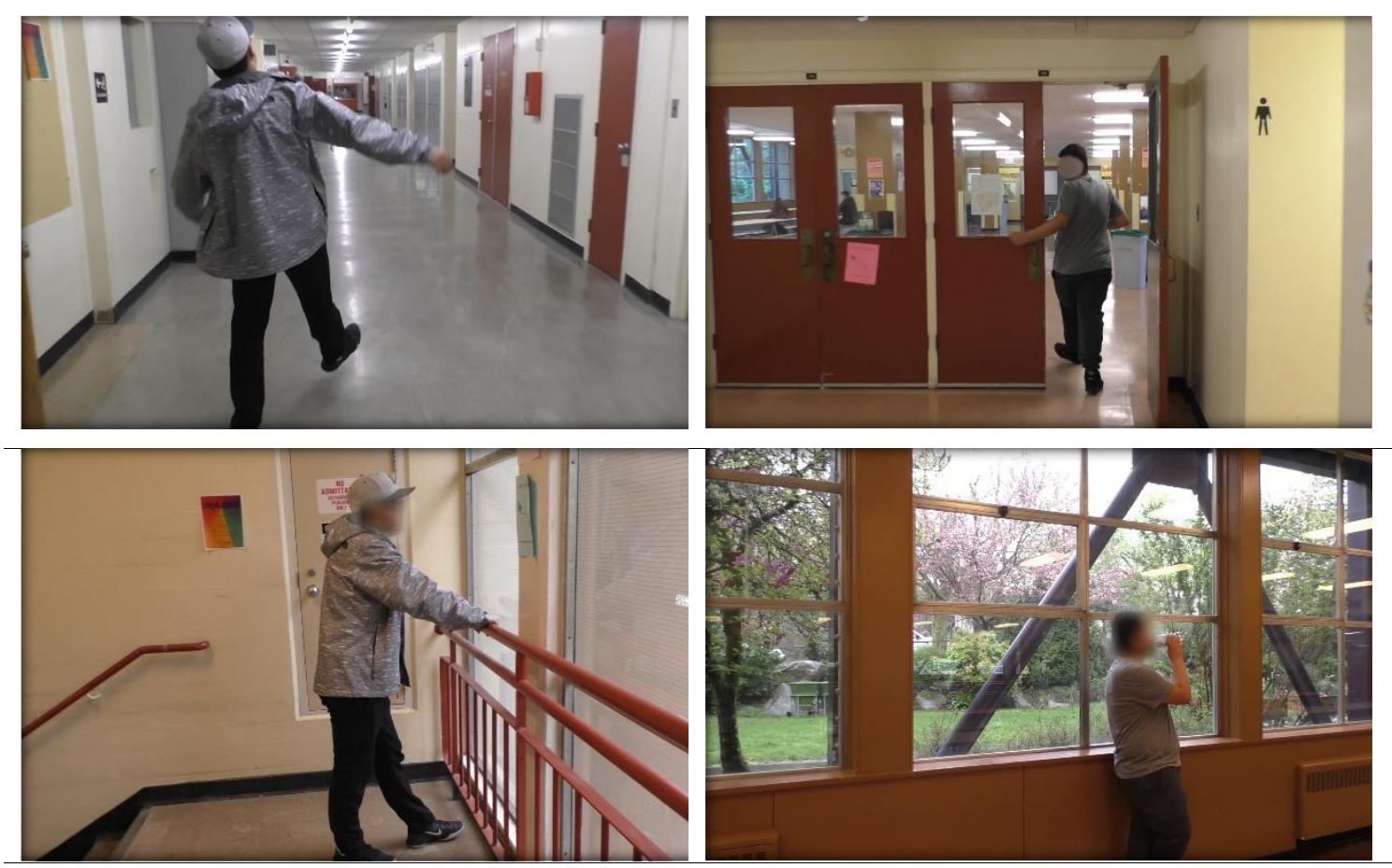

Figure 3. Chen and Ahmed playfully roaming and 'claiming' school spaces in their videos

The following excerpt illustrates one moment of lighthearted role-play, when Ahmed interviewed Chen off-camera, and I wrote Ahmed's paraphrases of Chen's answers as he could not. In this excerpt, Chen (interviewee) explained to Ahmed (interviewer) what a phone is like for him

\section{Excerpt 2:}

Chen: For me... phone is my best friend. For, when I was feel bad I can talk with my phone. Like, yeah, I can... 
Ahmed brings his phone close to his mouth.

Ahmed: Like this? Hello? Hello?

All laughing.

Amir: Give it a rose.

Chen: Like... I will... play the games... in my phone. Read books in my phone...

Amir: Nice.

Chen: And listen to music in my phone...

Amir: Nice.

Chen: Like, everything -

Amir: Wait, it's...

Ahmed and Chen burst out laughing.

Amir: He [Ahmed] needs to rephrase everything.

In their roles as interviewer and interviewee, as evident in this excerpt, Chen and Ahmed took up the discourse of the interview playfully. While Chen was highly engaged in his interviewee role and responded to Ahmed elaborately, Ahmed listened carefully to Chen, and jokingly commented on Chen's remark that when he felt bad, he could talk with his phone. This side-note by Ahmed was typical of his sense of humor, which helped him cope with stressful situations at school and was arguably one of his assets. The role-play of interviewer and interviewee-although it was effortful for the youth-also allowed for a kind of playfulness to emerge that dissolved some of the pressures that the roles induced or heightened, and welcomed the kind of humor that Ahmed expressed in this excerpt. The excerpt further illustrates how role-play involved playfully testing, appropriating and internalizing a set of behaviors - in this case, of interviewers and interviewees-without the risks of doing so in 'real life' (Bruner, 1983; Kendrick et al., 2018). This was especially evident in the excerpt when I paused Chen's speech to provide time for Ahmed to rephrase it, and was quickly joined by a loud laugh from both youth, with Chen himself realizing how engaged he was in his role as interviewee.

Navigating the new power relations instigated by their roles, Chen and Ahmed's accentuation of collaboration over coercion was evident in their playfulness. In numerous occasions, they would humorously call each other "handsome", or jokingly mention that they would give each other "Guangzhou" (meaning "rosebud" in Turkish). In their postproject interview, both mentioned that they enjoyed working with each other and that my facilitation was helpful in managing the challenges of this project. As Goodman notes about students' apprenticeship in filmmaking, "The students' story, as much as it is about the production of a video and the development of a learning process, also turns out to be a web of relationships: those that formed between learner and learner, learner and teacher, learner and documentarian, learner and subject matter, and learner and video technology" (2003, p. 66). On a smaller scale - substantial nevertheless - this project afforded Chen and Ahmed roles through which they could playfully enhance their web of relationships, of which I was also part, as a facilitator, along with the technology.

From a multiliteracies (New London Group, 1996), sociocultural approach to literacy (Street, 1984), youth's playful accentuation of collaborative power relations (Cummins, 2000), considering the challenges instigated or heightened by their roles, mediated their apprenticeship in DMC practices and tools. Their collaborative power relations formed a ZPD, bridging for them the distance from how they would perform independently in these practices to how they could do so under the collaborative guidance 
of peers and a supportive adult (Vygotsky, 1978). This was made possible - to a large extent-by role-play.

From a play-based approach, role-play instigated or heightened communicative challenges by pushing youth into unfamiliar roles (Cazden, 1997; Vadeboncoeur, 2017; Vygotsky, 1978), but also allowed for a playful and risk-free experimentation in these roles (Kendrick et al., 2018; Soep, 2005) that helped them manage the communicative challenges and establish collaborative (rather than coercive) power relations.

\section{Repositioning and Representing their Imagined Identities}

In what came to be their identity texts (Cummins \& Early, 2011), the youth interviewed each other, chose from footage depicting each other, and edited each other's voices telling the other's story. Therefore, in the various sessions, but more so in editing, the youth constantly grappled with reflections of themselves (their identity-positionings; Golden \& Pandya, 2019) — most often through their eyes but also through their peer's eyes - as they performed the different roles. However, they also agentively took up the opportunities made available by role-play to reposition their identities, in their interactions and in multimodal form in their videos. This section unpacks these two aspects of youth's DMC process as identity positioning and repositioning instigated by role-play.

As editors and directors, the youth had their bodies, voices, and movements reflect at them from the screen and speakers as they viewed footage of themselves walking and talking in front of the camera, or as they heard themselves speaking in each other's interviews. Chuckles, giggles, laughter, and playfulness all served to mitigate and attenuate the embarrassment associated with these reflections, but they also hinted that the youth were grappling with how they positioned themselves and how they were positioned by others (Soep, 2005). Ahmed, for example, jokingly said of himself in a shot in the food court "I'm looking crazy", and asked Chen why he recorded so many takes of him.

The youth were particularly preoccupied with their identity positionings as English speakers. In the post-project interview, Chen explained that it was difficult for him to hear his spoken English, and Ahmed mentioned his "bad English". Such moments illustrate deficit-oriented positionings of their identities as English speakers, but also as adolescents who were insecure about how they looked and sounded. It is crucial to understand how prominent such deficit-oriented identity positionings can be for newcomer students who are emerging bi/multilinguals (García, 2009) in a predominantly English-speaking environment, as the youth's role-play in DMC highlighted in this project. Importantly, although the pattern was evident for both Chen and Ahmed, it was more pronounced for Ahmed.

In the following excerpt, Ahmed, as editor, asked Chen to explain to him how to cut and move audio clips in the editing software's timeline, and Chen, as director, exhibited impatience for having to work hard to understand Ahmed:

\section{Excerpt 3:}

Ahmed: Hhhow cutting, how...? Stopping this and stopping?

Chen: It's play and stop.

Ahmed: Which, which one is...cutting?

Chen: What cut? What do you want?

Ahmed: Cut is this, like this, man.

Ahmed: Like this (circling an area on the timeline with the cursor). 
Chen: What, you want to make sh.. make that close? (pointing with the cursor on a gap between two audio clips)

Chen: So... Look at my hand, look at my hand. Hold this one (left button on the mouse). Chen: Like this (dragging to make a selection).

Amir: Drag.

Chen: Take it here (selecting the audio clip).

Ahmed: Yeah.

Amir: Select and drag.

Ahmed: (to Chen) Okay hara.

Chen continues making editorial actions.

Ahmed: Okay, okay. I understand.

The excerpt highlights how Chen and Ahmed, in their roles as director and editor, respectively, navigated the tensions of their new power relations: Chen lost some of his patience with Ahmed's communication and digital literacy challenges (e.g., selecting and dragging clips), whereas Ahmed responded with resistance and a clear attempt to reposition his identity to that of competent editor and English speaker ("Okay hara", "Okay, okay. I understand."), as opposed to Chen's positioning of him as incomprehensible ("What cut? What do you want?").

Ahmed's use of the Arabic curse word 'hara', which means feces, was an attempt to project this frustration outward and resist a positioning of his identity as incomprehensible. In the context of their class, this word had already become Ahmed's catchphrase, as he would often tease his classmates by calling them "hara-boy". Despite the term's derogatory tone, members of the class, including Chen, would typically not be personally offended, because Ahmed would use the label for everyone, including himself. Therefore, 'hara' in this excerpt was not alarming for Chen in any visible way. However, the use of the word clearly signaled Ahmed's frustration with and resistance to Chen's positioning of him.

The various roles that the youth had to play, including those of editors and filmed subjects, highlighted their identity as a site of struggle (Norton, 2013). In these roles, they were often confronting their own and others' positionings of their identity, and tried to reposition them (Golden \& Pandya, 2019). As Kendrick (2005) previously argued with regard to play for children, role-play in DMC made visible the youth's imagined identities and positionings; how they positioned each other and repositioned themselves in their school setting.

Beyond grappling with ways their identities were positioned in their own eyes or their peer's eyes, both Ahmed and Chen mentioned that they enjoyed the experience of composing a video for the first time with close guidance. As they performed in roles that were new to them and took risks without real-world consequences (Bruner, 1983; Kendrick et al., 2018), they acquired social and cultural capital, and were able to experience themselves anew, arguably with added agency, power, and purpose, considering the potential identities that they could assume in the future as proficient English speakers and video composers.

Agentively taking up the roles of director, narrator, editor, filmed subject, cameraperson, as well as interviewer and interviewee, afforded both Chen and Ahmed positions of power and an opportunity to imagine themselves differently. Through playful performance, which was captured in their interactions and videos (e.g., through gestures, 
camera angles, music), they were apprenticed in these roles, and could thus envision their future competence (Cazden, 1997) and belonging to different imagined professional communities, such as video editors. Therefore, working on the project not only reflected to them what they or others considered to be missing in themselves, but also provided them a positive view — a repositioning, reimagining — of their identities. As Cummins and Early (2011) argued vis-à-vis identity texts, role-play held "a mirror up to students in which their identities are reflected back in a positive light" (p. 3).

Furthermore, Chen and Ahmed highlighted the learning experience of working on their spoken English in the various roles, but especially as narrators in voice-over recording and editing sessions. This afforded them heightened awareness of their spoken English and concrete representations of how proficient they could become.

On one occasion, Chen (as editor for Ahmed) noticed in the editing phase that Ahmed, in his voiceover, pronounced Chen's home country as "Chinok" instead of "China". In Ahmed's response to Chen's comment about it, it was evident that Ahmed was not sure about the pronunciation even during the editing phase. Chen then used the multimodal literacy practice he had already learned through my guidance to trim the audio clip and fade it out before the consonant sound " $\mathrm{k}$ " in Chinok could be heard. When playing the clip after conducting this trimming procedure, Chen proudly uttered "Ha ha!" while Ahmed paid attention intently. During this and other occasions, taking their recorded speech and transforming it through editing into a streaming, uninterrupted voiceover narration arguably served to concretely model for them the proficient English speaker that they could become, as previously demonstrated with ELLs in the context of video selfmodeling (Boisvert \& Rao, 2015). For Ahmed, this process consisted of picking moments in which he pronounced parts of sentences intelligibly and putting those together on the timeline, with appropriate breaks that simulated naturally-occurring speech.

From a multiliteracies, sociocultural approach to literacy, role-play in this project reflected back to youth deficit-oriented positionings of their identity, but it also served as a ZPD that facilitated their performance of multimodal literacy practices in advance of their actual level (Cazden, 1997). Role-play, as a form of learning in the ZPD allowed them to experiment with ways of repositioning and concretely representing their imagined identities: first, because they playfully performed as director, editor, cameraperson, and so on, before being competent in those roles, they were able reposition their identities as belonging to a variety of imagined communities associated with these roles; second, as they edited their speech to create an enhanced - imaginary yet audible-version of their imagined identities as proficient English speakers, they could tangibly represent themselves claiming those imagined identity positionings in DMC. It is through such roleplay that the youth were so invested (Norton, 2013) and engaged in handling the challenges that the project's multimodal literacy practices entailed, as the social and cultural capital that they possessed and that which they hoped to obtain (e.g., web of relationships and English language proficiency) was affirmed and developed.

\section{Conclusions and Implications}

This case study reveals two ways in which newcomer youth navigated the DMC process through role-play in their school setting. As discussed below, these two patterns have important implications for educators and researchers considering DMC as a classroom 
literacy practice, especially with play or role-play, in order to learn about and advance newcomer youth's engagement in literacy practices in school settings.

First, as the youth were invited to play a variety of roles that positioned them in specific power relations different from their everyday relationship as peers, they faced communicative challenges and the burden of responsibility for moving the production forward, which instigated or heightened tensions in their relationship. The study thus highlights for educators and researchers what kinds of communicative challenges and tensions may be involved for newcomers in assuming roles in DMC in school settings. Especially, the study shows how effects of different migration backgrounds, such as interrupted schooling and coming late to literacy, can play into these challenges and tensions, but also the coping strategies that individual students might have to address them, such as Ahmed's use of humor, his projection of frustration, and his determined repositioning of his identity in interaction with Chen.

Because of the emphasis on role-play and youth's playful take-up of the roles, they were ultimately able to attenuate the tensions and accentuate collaborative over coercive power relations through recurring and prolonged laughter and playfulness that engendered the liberating force of play. This thematic pattern highlights how important youth's collaborative power relations were, including my own role as facilitator, for mediating their apprenticeship in multimodal literacy practices in a ZPD. Therefore, the study directs educators and researchers' attention to the potential of play and role-play for facilitating such collaborative creation of power in DMC among newcomer youth and invites further exploration of this potential with newcomer youth from different backgrounds, in different groupings, and in different school contexts.

Second, as youth played their roles in producing their identity texts, they grappled with reflections of deficit-oriented identity-positionings of themselves in roleperformance, especially with regards to their appearance and proficiency in English. However, because of the risk-free quality of their role-play, youth were also able to reposition their identities through role-play to include imagined identities, and represent some of those concretely in DMC, such as editing their speech to represent their imagined identities as proficient English speakers. Role-play thus served as a form of learning in the ZPD that facilitated their performance of multimodal literacy practices in advance of their actual level. This thematic pattern serves as a reminder for educators and researchers of how fraught newcomer youth's identities can be as sites of struggle, especially if they are bi/multilinguals in environments that predominantly favor proficiency in specific languages that are not their L1. This pattern also raises the question of what pedagogies can be employed to make newcomer youth's struggles visible and help them manage those in school settings. Alongside attempts to change societal discourses in school contexts, facilitating role-play in DMC may be one way of beginning to do that, as in this study it allowed youth to play with their communicative repertoires, offered them a means of repositioning and reimagining their identities, and made those imagined identities visible.

DMC - especially filmmaking - as a $21^{\text {st }}$ century multimodal literacy practice, often necessitates collaboration among composers who need to enter and exit different roles during the design process. Although such roles are not necessarily fully distinct from each other and may overlap, becoming adept at moving comfortably between them is one important way of learning how to compose in multiple modes using digital technologies. 
As this study shows, it is also a playful test frame for identity positionings and an exercise in fostering relationships with peers.

This study shows how role-play in newcomer youth's DMC process was grounded in their relationships and imagined identities; it invites educators and researchers to be mindful of how meaningful role-play in DMC can be for affirming such learners' identities, for recognizing their investment and fostering their engagement in language and literacy learning. Newcomer learners, especially those from refugee backgrounds, marginalized communities, or low-SES backgrounds, deserve every effort on the part of educators and researchers to advance this goal.

\section{References}

Anderson, B. (1983). Imagined communities: Reflections on the origin and spread of nationalism. Verso books.

Appadurai, A. (1996). Modernity al large: Cultural dimensions of globalization. University of Minnesota Press.

Bakhtin, M. (1984). Rabelais and his world (H. Iswolsky, Trans.). Indiana University Press.

Barton, D., \& Hamilton, M. (2000). Literacy practices. In D. Barton, M. Hamilton, \& R. Ivanič (Eds.), Situated literacies: Reading and writing in context (pp. 7-15). Psychology Press.

Bateman, J. (2014). Text and image: A critical introduction to the visual/verbal divide. Routledge.

BC Ministry of Education. (2017). English language learning (ELL) standards. https://victesol.vic.edu.au/wp-content/uploads/British-Columbia-ell-standardsfull.pdf

Boisvert, P., \& Rao, K. (2015). Video self-modeling for English language learners. TESOL Journal, 6(1), 36-58. https://doi.org/10.1002/tesj.135

Braun, V., \& Clarke, V. (2006). Using thematic analysis in psychology. Qualitative Research in Psychology, 3(2), 77-101. https://doi.org/10.1191/1478088706qp063oa

Braun, V., \& Clarke, V. (2012). Thematic analysis. In H. Cooper, P. M. Camic, D. L. Long, A. T. Panter, D. Rindskopf, \& K. J. Sher (Eds.), APA handbooks in psychology®. APA handbook of research methods in psychology, Vol. 2. Research designs: Quantitative, qualitative, neuropsychological, and biological (pp. 57-71). American Psychological Association.

Bruner, J. (1983). Play, thought, and language. Peabody Journal of Education, 60(3), 6069. https://doi.org/10.1080/01619568309538407

Burke, A., \& Hardware, S. (2015). Honouring ESL students' lived experiences in school learning with multiliteracies pedagogy. Language, Culture and Curriculum, 28(2), 143-157. https://doi.org/10.1080/07908318.2015.1027214

Cazden, C. B. (1997). Performance before competence: Assistance to child discourse in the zone of proximal development. In M. Cole, Y. Engestrom, \& O. Vasquez (Eds.), Mind, culture, and activity: Seminal papers from the Laboratory of Comparative Human Cognition (pp. 303-310). Cambridge University Press. 
Coffey, A., \& Atkinson, P. (1996). Making sense of qualitative data: Complementary research strategies. Sage Publications, Inc.

Cope, B., \& Kalantzis, M. (2005). A pedagogy of multiliteracies designing social futures. In B. Cope \& M. Kalantzis (Eds.), Multiliteracies: Literacy Learning and the Design of Social Futures (pp. 19-46). Routledge.

Cummins, J. (2000). Language, power and pedagogy: Bilingual children in the crossfire. Multilingual Matters.

Cummins, J., \& Early, M. (2011). Identity texts: The collaborative creation of power in multilingual schools. Trentham Books.

Cummins, J., Hu, S., Markus, P., \& Kristiina Montero, M. (2015). Identity texts and academic achievement: Connecting the dots in multilingual school contexts. TESOL Quarterly, 49(3), 555-581. https://doi.org/10.1002/tesq.241

Cummins, J., Mirza, R., \& Stille, S. (2012). English language learners in Canadian schools: Emerging directions for school-based policies. TESL Canada Journal, 29(6), 25-48. https://doi.org/10.18806/tesl.v29i0.1121

Cummins, J., Ntelioglou, B. Y., Prasad, G., \& Stille, S. (2017). Identity text projects. In J. B. Cummings \& M. L. Blatherwick (Eds.), Creative Dimensions of Teaching and Learning in the 21st Century (pp. 69-76). SensePublishers, Rotterdam.

Custodio, B., \& O'Loughlin, J. B. (2017). Students with interrupted formal education: Bridging where they are and what they need. Corwin Press.

De Castell, S., \& Jenson, J. (2003). OP-ED serious play. Journal of Curriculum Studies, 35(6), 649-665. https://doi.org/10.1080/0022027032000145552

Dewey, J. (1916). Democracy and education. New York: Macmillan.

Dicks, B., Flewitt, R., Lancaster, L., \& Pahl, K. (2011). Multimodality and ethnography: Working at the intersection. Qualitative Research, 11(3), 227-237. https://doi.org/10.1177/1468794111400682

Early, M., Dagenais, D., \& Carr, W. (2017). Second language education in Canada. In N. Van Deusen-Scholl \& S. May (Eds.), Second and Foreign Language Education, Encyclopedia of Language and Education (pp. 313-326). https://doi.org/10.1007/978-3-319-02246-8_27

Early, M., \& Marshall, S. (2008). Adolescent ESL students' interpretation and appreciation of literary texts: A case study of multimodality. Canadian Modern Language Review, 64(3), 377-397. https://doi.org/10.3138/cmlr.64.3.377

Fisher, S., Jenson, J., Lotherington, H., Florence, S., \& Lee, C. (2017). Learning as play. In H. Lotherington \& C. Paige (Eds.), Teaching Young Learners in a Superdiverse World (pp. 54-70). Routledge. https://doi.org/10.4324/9781315626079-4

Flewitt, R. (2011). Bringing ethnography to a multimodal investigation of early literacy in a digital age. Qualitative Research, 11(3), 293-310. https://doi.org/10.1177/1468794111399838

Friese, S., Soratto, J., \& Pires, D. (2018). Carrying out a computer-aided thematic content analysis with ATLAS.ti. MMG Working Paper, 18(02), 1-29.

García, O. (2009). Emergent bilinguals and TESOL: What's in a name? TESOL Quarterly, 43(2), 322-326. https://doi.org/10.1002/j.1545-7249.2009.tb00172.x

Giampapa, F. (2010). Multiliteracies, pedagogy and identities: Teacher and student voices from a Toronto elementary school. Canadian Journal of Education, 33(2), 407-431. 
Golden, N. A., \& Pandya, J. Z. (2019). Understanding identity and positioning for responsive critical literacies. Language and Education, 33(3), 211-225. https://doi.org/10.1080/09500782.2018.1497648

Goodman, S. (2003). Teaching youth media: A critical guide to literacy, video production and social change (Vol. 36). Teachers College Press.

Gumperz, J. (1999). On interactional sociolinguistic method. In S. Sarangi \& C. Roberts (Eds.), Talk, work and institutional order: Discourse in medical, mediation and management settings (Vol. 453, pp. 453-472). Mouton de Gruyter.

Gunderson, L. (2007). English-only instruction and immigrant students in secondary schools: A critical examination. Laurence Erlbaum Associates.

Hafner, C. A. (2018). Visual design and multimodal composing. In J. I. Liontas \& M. DelliCarpini (Eds.), The TESOL Encyclopedia of English Language Teaching (pp. 1-7). John Wiley \& Sons, Inc.

Harré, R., \& Langenhove, L. V. (1991). Varieties of positioning. Journal for the Theory of Social Behaviour, 21(4), 393-407. https://doi.org/10.1111/j.14685914.1991.tb00203.x

Hepple, E., Sockhill, M., Tan, A., \& Alford, J. (2014). Multiliteracies pedagogy: Creating claymations with adolescent, post-beginner English language learners. Journal of Adolescent \& Adult Literacy, 58(3), 219-229. https://doi.org/10.1002/jaal.339

Holland, D. C., Lachicotte Jr, W., Skinner, D., \& Cain, C. (2001). Identity and agency in cultural worlds. Harvard University Press.

Huizinga, J. (1950). Homo ludens: A study of the play-element in culture. Beacon Press.

Jewitt, C. (2008). Multimodality and literacy in school classrooms. Review of Research in Education, 32(1), 241-267. https://doi.org/10.3102/0091732X07310586

Jiang, L. (2018). Digital multimodal composing and investment change in learners' writing in English as a foreign language. Journal of Second Language Writing, 40, 60-72. https://doi.org/10.1016/j.jslw.2018.03.002

Karam, F. J. (2018). Language and identity construction: The case of a refugee digital bricoleur. Journal of Adolescent \& Adult Literacy, 61(5), 511-521. https://doi.org/10.1002/jaal.719

Kendrick, M. (2005). Playing house: A 'sideways' glance at literacy and identity in early childhood. Journal of Early Childhood Literacy, 5(1), 5-28. https://doi.org/10.1177/1468798405050592

Kendrick, M., Early, M., \& Chemjor, W. (2018). Designing multimodal texts in a girls' afterschool journalism club in rural Kenya. Language and Education, 33(2), 123 140. https://doi.org/10.1080/09500782.2018.1516777

Kim, S. (2018). "It was kind of a given that we were all multilingual": Transnational youth identity work in digital translanguaging. Linguistics and Education, 43, 3952. https://doi.org/10.1016/j.linged.2017.10.008

Kress, G. (2010). Multimodality: A social semiotic approach to contemporary communication. Routledge.

Lotherington, H., \& Jenson, J. (2011). Teaching multimodal and digital literacy in L2 settings: New literacies, new basics, new pedagogies. Annual Review of Applied Linguistics, 31, 226-246. https://doi.org/10.1017/S0267190511000110 
Low, D. E., \& Pandya, J. Z. (2019). Issues of validity, subjectivity, and reflexivity in multimodal literacy research and analysis. Journal of Language and Literacy Education, 15(1), 1-22.

Mardell, B., Wilson, D., Ryan, J., Ertel, K., Krechevsky, M., \& Baker, M. (2016). Towards a pedagogy of play (a Project Zero working paper). Harvard Graduate School of Education.

Maxwell, J. A. (1992). Understanding and validity in qualitative research. Harvard Educational Review, 62(3), 279-301. https://doi.org/10.17763/haer.62.3.8323320856251826

Maxwell, J. A. (2012). Qualitative research design: An interactive approach. Sage.

Maxwell, J. A., \& Chmiel, M. (2013). Notes toward a theory of QDA. In U. Flick (Ed.), The SAGE handbook of qualitative data analysis (pp. 21-34). Sage.

Maxwell, J. A., \& Miller, B. A. (2008). Categorizing and connecting strategies in qualitative data analysis. In S. N. Hesse-Biber \& P. Leavy (Eds.), Handbook of emergent methods (pp. 461-477). The Guilford Press.

McBrien, J. L. (2005). Educational needs and barriers for refugee students in the United States: A review of the literature. Review of Educational Research, 75(3), 329364. https://doi.org/10.3102/00346543075003329

Medina, C. L., \& del Rocío Costa, M. (2013). Latino media and critical literacy pedagogies: Children's scripting of telenovelas discourses. Journal of Language and Literacy Education, 9(1), 161-184.

Medina, C. L., \& Wohlwend, K. E. (2014). Literacy, play and globalization: Converging imaginaries in children's critical and cultural performances. Routledge.

Miles, M. B., Huberman, A. M., \& Saldana, J. (2020). Qualitative data analysis: A methods sourcebook. Sage.

Nagle, J., \& Stooke, R. (2016). Railways, rebellions and rage against the machine: Adolescents' interests and meaning-making in the creation of multimodal identity texts. Literacy, 50(3), 158-165. https://doi.org/10.1111/lit.12081

New London Group. (1996). A pedagogy of multiliteracies: Designing social futures. Harvard Educational Review, 66(1), 60-93.

$\mathrm{Ng}, \mathrm{C} .$, \& Graham, S. (2018). Improving literacy engagement: Enablers, challenges and catering for students from disadvantaged backgrounds. Journal of Research in Reading, 41(4), 615-624. https://doi.org/10.1111/1467-9817.12252

Norton, B. (2013). Identity and language learning: Extending the conversation. Multilingual Matters.

Oikonomidoy, E., Salas, R. G., Karam, F. J., Warren, A. N., \& Steinmann, T. (2019). Locating newcomer students in educational research in the US: A review of the literature from 2000-2017. Pedagogy, Culture \& Society, 27(4), 575-594. https://doi.org/10.1080/14681366.2018.1542539

Pandya, J. Z. (2019). Exploring critical digital literacy practices: Everyday video in a dual language context. Routledge.

Pandya, J. Z., \& Mills, K. A. (2019). Bakhtin and the carnival: Humour in school children's film making. Language and Education, 33(6), 544-559. https://doi.org/10.1080/09500782.2019.1629954

Prasad, G. (2018). Building students' language awareness and literacy engagement through the creation of collaborative multilingual identity texts 2.0. In H. Hélot, 
C. Frijns, \& K. Gorp (Eds.), Language Awareness in Multilingual Classrooms in Europe: From Theory to Practice. (pp. 207-234). Mouton De Gruyter Publishers.

Reynolds, A. D., \& Bacon, R. (2018). Interventions supporting the social integration of refugee children and youth in school communities: A review of the literature. Advances in Social Work, 18(3), 745-766. https://doi.org/10.18060/21664

Serafini, F., \& Gee, E. (2017). Remixing multiliteracies: Theory and practice from New London to new times. Teachers College Press.

Shapiro, S., Farrelly, R., \& Curry, M. J. (Eds.). (2018). Educating refugee-background students: Critical issues and dynamic contexts. Multilingual Matters.

Sicart, M. (2014). Play matters. MIT Press.

Smagorinsky, P. (2001). If meaning is constructed, what is it made from? Toward a cultural theory of reading. Review of Educational Research, 71(1), 133-169. https://doi.org/10.3102/00346543071001133

Smagorinsky, P. (2008). The method section as conceptual epicenter in constructing social science research reports. Written Communication, 25(3), 389-411. https://doi.org/10.1177/0741088308317815

Smith, B. E. (2014). Beyond words: A review of research on adolescents and multimodal composition. In R. E. Ferdig \& K. E. Pytash (Eds.), Exploring multimodal composition and digital writing (pp. 1-19). IGI Global.

Smith, B. E., Pacheco, M. B., \& Khorosheva, M. (2020). Emergent bilingual students and digital multimodal composition: A systematic review of research in secondary classrooms. Reading Research Quarterly, 56(1), 33-52. https://doi.org/10.1002/rrq.298

Soep, E. (2005). Making hard-core masculinity: Teenage boys playing house. In S. Maira \& E. Soep (Eds.), Youthscapes: The popular, the national, the global (pp. 173191). University of Pennsylvania Press.

Streeck, J., \& Mehus, S. (2005). Microethnography: The study of practices. In K. L. Fitch \& R. E. Sanders (Eds.), Handbook of language and social interaction (pp. 381404). Psychology Press.

Street, B. (1984). Literacy in theory and practice (Vol. 9). Cambridge University Press.

Sutton-Smith, B. (1997). The ambiguity of play. Harvard University Press.

Taylor, C. (2004). Modern social imaginaries. Duke University Press.

Taylor, C. (2007). A secular age. Harvard University Press.

Toohey, K., \& Derwing, T. M. (2008). Hidden losses: How demographics can encourage incorrect assumptions about ESL high school students' success. Alberta Journal of Educational Research, 54(2), 178-193.

Vadeboncoeur, J. A. (2017). Vygotsky and the promise of public education. Peter Lang. Vasudevan, L. (2015). Multimodal play and adolescents: Notes on noticing laughter. Journal of Language and Literacy Education, 11(1), 1-12.

Vasudevan, L., DeJaynes, T., \& Schmier, S. (2010). Multimodal pedagogies. In D. E. Alvermann (Ed.), Adolescents' online literacies: Connecting classrooms, digital media and popular culture (pp. 5-25). Peter Lang.

Vygotsky, L. S. (1926). Educational psychology (R. Silverman, Trans.). Boca Raton, FL: St. Lucie Press. [Lectures written in 1921-1923, first publication in Russian in 1926.]. 
Vygotsky, L. S. (1933). Play and its role in the mental development of the child. Soviet Psychology, 5(3), 6-18. https://doi.org/10.2753/RPO1061-040505036

Vygotsky, L. S. (1978). Mind in society: The development of higher psychological processes. Harvard University Press.

Warriner, D. S., Fredricks, D. E., \& Duran, C. S. (2020). Valuing the resources and experiences of refugee-background learners: A principled approach to teaching and learning academic language. Theory into Practice, 59(1), 32-41.

Watt, D., \& Roessingh, H. (1994). Some you win, most you lose: Tracking ESL student drop out in high school (1988-1993). English Quarterly, 26(3), 5-7.

Watt, D., \& Roessingh, H. (2001). The dynamics of ESL drop-out: Plus ça change.... Canadian Modern Language Review, 58(2), 203-222. https://doi.org/10.3138/cmlr.58.2.203

Wenger, E. (1999). Communities of practice: Learning, meaning, and identity. Cambridge University Press.

Wertsch, J. V. (2009). Voices of the mind: Sociocultural approach to mediated action. Harvard University Press.

Wohlwend, K. E. (2018). Play as the literacy of children. In D. E. Alvermann, N. J. Unrau, M. Sailors, \& R. B. Ruddell (Eds.), Theoretical Models and Processes of Literacy (7th ed., pp. 301-318). Routledge. https://doi.org/10.4324/9781315110592-18

Wohlwend, K. E., Buchholz, B. A., \& Medina, C. (2017). Playful literacies and practices of making in children's imaginaries. In K. A. Mills, A. Stornaiuolo, A. Smith, \& J. Z. Pandya (Eds.), Handbook of writing, literacies and education in digital cultures (pp. 136-147). Routledge.

Woolf, N., \& Silver, C. (2018). Qualitative analysis using ATLAS. ti: The five-level QDA method. Routledge.

Yin, R. K. (2018). Case study research and applications: Design and methods. Sage.

Zapata, G. C., \& Ribota, A. (2020). The instructional benefits of identity texts and learning by design for learner motivation in required second language classes. Pedagogies: An International Journal, 16(1), 1-18. https://doi.org/10.1080/1554480X.2020.1738937

Author Biography

Amir Michalovich is a PhD Candidate in the Department of Language and Literacy Education at the University of British Columbia. His dissertation research explores digital multimodal composition among refugee-background youth. His research and teaching explore digital multimodal composition, media literacy, qualitative data analysis, and classroom interaction. https://orcid.org/0000-0001-7226-3254 
Appendix

Table 1

Six stages used to conduct thematic analysis

Stage $\quad$ Stage operationalization in ATLAS.ti 8 (software features in SMALL

1. Familiarization - Manually transcribe session recordings and sync transcripts with with the data recordings in ATLAS.ti. Youth's video footage is not transcribed, but rather segmented, commented on and coded directly in ATLAS.ti in stages one and two.

- Create QuOTATIONS (segmented pieces of data; Coffey \& Atkinson, 1996) relevant to the research question. For each QUOTATION, create brief COMMENT and address semantic and latent levels of meaning (implicit and explicit meanings of statements or actions) by asking:

1. What is going on? (Streeck \& Mehus, 2005)

2. What meanings are communicated in different modes (in the youth's footage)? (Kress, 2010)

3. How might my inferences be wrong? (Maxwell, 2012)

- From this stage onwards, write extensively about ideas for inferences in a running research journal MEMO.

2. Generating - Look for similarities (Maxwell \& Miller, 2008) among QUOTATIONS initial codes by tagging them with:

- Organizational CODES (Maxwell \& Chmiel, 2013), such as Rich quotes and CODES for roles (e.g., Role: Director), modes (only for youth's videos; e.g., Mode: Audial: Music), and participants (e.g., @Chen);

- Substantive CODEs (Maxwell \& Chmiel, 2013), such as Playfulness \& laughter (see Figure 2).

- Review CODES and their content, reassign QUOTATIONS as necessary; define CODES; revise CODE list.

3. Searching for themes
- Look for connections (Maxwell \& Miller, 2008) among QUOTATIONS and CODES, and propose thematic patterns:

- Create CODE CO-OCCURRENCE TABLES to explore intersections between CODES, i.e., if/how different CODES were applied to the same QUOTATIONS (e.g., role CODES as rows and substantive CODES as columns).

- In NETWORK VIEW, create concept maps to explore how CODES are related; create LINKS between CODES (e.g., Role mannerisms is related to Shifting responsibilities).

- Construct CODE CO-OCCURRENCE TABLES to explore Rich quotes for each substantive CODE.

- In NETWORK VIEW, cluster CODES around potential themes (substantive or theoretical CODES; Maxwell \& Chmiel, 2013), such as Reflection of imagined identities as integral to composition. 


\begin{tabular}{|c|c|c|}
\hline & $\begin{array}{l}\text { Reviewing } \\
\text { potential } \\
\text { themes }\end{array}$ & $\begin{array}{l}\text { - Construct CODE DOCUMENT TABLES to explore the prevalence of } \\
\text { emerging themes across sessions. } \\
\text { - Construct CODE CO-OCCURRENCE TABLES to explore the prevalence of } \\
\text { substantive CODES across participants. } \\
\text { - Draft a MEMO for each theme and note especially rich QUOTATIONS. }\end{array}$ \\
\hline 5. & $\begin{array}{l}\text { Defining and } \\
\text { naming themes }\end{array}$ & $\begin{array}{l}\text { - Review and revise theme MEMOS; situate in existing literature. } \\
\text { - } \quad \text { Reduce themes further as part of manuscript revision. }\end{array}$ \\
\hline 6. & $\begin{array}{l}\text { Producing the } \\
\text { report }\end{array}$ & $\begin{array}{l}\text { - Export theme MEMOS for writing (and later rewriting) the findings } \\
\text { and discussion section. } \\
\text { - Export visualization to show development of substantive CODES and } \\
\text { theoretical CODES (initial themes) into final themes (Figure 2). }\end{array}$ \\
\hline
\end{tabular}

